\title{
A Curious Tale of Economics and Common Carriage (Net Neutrality) at the FCC: A Reply to Faulhaber, Singer, and Urschel
}

\author{
DWAYNE WINSECK ${ }^{1}$ \\ Carleton University, Canada \\ JEFFERSON D. POOLEY \\ Muhlenberg College, USA
}

\begin{abstract}
This reply to "The Curious Absence of Economic Analysis at the Federal Communications Commission" by Faulhaber, Singer, and Urschel makes three claims. First, we document the paper's undisclosed origins as a white paper commissioned by an advocacy group with deep ties to the telecommunications industry. Second, we describe two of the authors' active participation, on behalf of clients, in a range of contested issues before the FCC in recent years. Finally, our review of FCC workshops, roundtables, seminars, dockets, and rulings-including during its landmark 2015 Open Internet Order and several blockbuster mergers and acquisitions-provides detailed evidence to refute the paper's core "curious absence" charge. The stakes could not be higher, we conclude, as the new FCC chair, Ajit Pai, has repeatedly referenced the paper to justify his rollback of FCC regulations-including, crucially, the common carriage/net neutrality rules so vigorously opposed by the paper's funders.
\end{abstract}

Keywords: broadband Internet access regulation, common carriage, net neutrality, economics, FCC, politics of knowledge, communication history

The title startled both of us: "The Curious Absence of Economic Analysis at the Federal Communications Commission" (Faulhaber, Singer, \& Urschel, 2017). The paper, authored by Gerald R. Faulhaber, Hal J. Singer, and Augustus H. Urschel, tells the story of the rise and fall of economic analysis at the FCC, with the Commission's landmark 2015 decision to reclassify broadband Internet access services as "common carriers"-the bedrock historical principle underpinning what most people know as "net neutrality"-held up as Exhibit A in support of the authors' "curious absence" allegation. They also lament the FCC's failure to conduct cost-benefit analyses-a reflection, they claim, of the agency's indifference to economics. And as the authors see it, populist forces have flooded the space once occupied by economics. John Oliver's 2014 late-night rant on net neutrality triggered, they complain, a tsunami of

\footnotetext{
${ }^{1}$ We would like to thank Christopher Ali, Sue Curry Jansen, Ben Klass, Catherine Middleton, Philip Napoli, Reza Rajabuin, John L. Sullivan, Greg Taylor, and the IJoC editorial and review team for their very helpful comments on earlier drafts of this paper.

Copyright (C) 2017 (Dwayne Winseck: dwayne.winseck@carleton.ca; Jefferson Douglas Pooley: pooley@muhlenberg.edu). Licensed under the Creative Commons Attribution Non-commercial No Derivatives (by-nc-nd). Available at http://ijoc.org.
} 
"four million angry letters" that temporarily crashed the Commission's website. The common carrier rules, adopted the next year, were a triumph of unruly populism over economic expertise (p. 1225).

The notion that economists have next to no influence at the FCC, however, struck us as odd. This must be, we thought, the first article ever published to claim that economists do not have enough influence on federal policy making. The story of social science and U.S. policy since World War II is the story of economics. ${ }^{2}$ More to the point, economists have been extensively-and disproportionatelyinvolved in FCC rule making for decades, this one included. What could the authors possibly mean?

Curious, we conducted a simple Google search on the paper's title. We quickly discovered that a longer version of the same paper had been submitted to the FCC's official docket, not once but twice, by a group called CALinnovates, first in July 2016 in the Broadband Privacy proceeding (Faulhaber \& Singer, 2016a) and again in August in the Business Data Services proceeding (Faulhaber \& Singer, 2016b). Both of these white papers had disclosed the funding from CALinnovates, an "advocacy" group with deep ties to the telecommunications industry. The IJOC follow-up, however, initially disclosed nothing, and made no mention of these earlier publications.

We contacted the authors on Twitter about the missing origins of their paper, and they replied that the disclosure had been omitted to anonymize the paper for review. They supplied IJoC with a terse footnote: "The authors would like to thank CALinnovates for funding." The paper's history as a commissioned, publicly available white paper that had, after all, been crafted with an eye to advancing the commissioning client's interests before the regulator remains hidden to the journal's readers.

Digging deeper, we learned that Singer and Faulhaber have been active in many hot-button issues before the FCC, including its landmark Open Internet Order in 2015-the main object of their criticism. They have been active in blockbuster mergers and acquisitions cases, on an unsuccessful legal appeal of the FCC's 2015 net neutrality rules, and in a volley of actions now under way by the Trump administration's new FCC chair, Ajit Pai.

The authors blame "populism" for displacing economics. They cite the public's 4 million comments on net neutrality as a damning case in point: "The voices-no matter how disconnected from the ultimate policy outcome-trumped whatever the economists had to say" (p. 1215). Just five days after IJoC published the article, Pai (2017b) gave a speech that twice called out the "Curious Absence" white paper (but with no mention of its provenance). The views of economists at the FCC "have become an afterthought," Pai charged. "Now is the time to restore the place of economic analysis at the FCC" (pp. 12 ). It was also time to set things right, he intoned, as he announced a new FCC Office of Economics and Data (OED) (p. 5).

So an industry front group funded research that got published in a leading academic journal. Soon it was cited by the country's top policy maker to justify his industry-friendly regulatory rollbacks.

2 The literature on economics' post-World War II policy influence is enormous (see, e.g., Bernstein, 2014; Franklin, 2016). 
This, we contend, is a case of information laundering. The paper's core claim that the FCC has "abandon[ed] the dismal science" (Faulhaber et al., 2017, p. 1215), moreover, does not hold water. We show that the record was stuffed full with the contributions of economists-including those of the authors. The agency has been working in earnest to bolster, not sideline, economic analysis-a conclusion in line with other researchers' findings (e.g., Copeland, 2013).

The stakes could not be higher, as Pai sprints to reverse the most prominent accomplishments of the Obama-era FCC. The IJoC paper, and its predecessors, are a touchstone for op-eds across think tanks and their blogs as well as the business and popular press. Pai has positioned the papers as a cornerstone of his rush to roll back FCC regulations. The authors' appeal to the authority of economics, as we document in some detail, cloaks a full-throated political project designed to remake communications markets along the lines that incumbent telecommunications, broadband Internet, and media industries have desired all along: voluntary net neutrality principles versus the strong common carrier rules adopted in 2015; greatly relaxed scrutiny of concentration in some telecommunications and television markets; and abandonment of the Obama-era FCC's proposal to allow stand-alone access to cable television services and set-top boxes. The authors have been fighting on this project's front lines for years in a bid to shape how the increasingly Internet- and mobile wireless-centric media universe will unfold in the years ahead. When they bemoan, in the IJoC paper, the "curious absence" of economists at the FCC, what they are really objecting to are their own policy losses. They want a do-over, in effect, and their paper is already helping that effort. If Pai's views prevail, the outcomes of these battles-arriving at a moment of profound technological change-could reverberate for decades. This is why Faulhaber, Singer, and Urschel's paper deserves to be taken so seriously, and why it demands a reply.

\section{Sponsored Research}

The IJoC article cannot be viewed in isolation. The authors were funded by CALinnovates, launched in early 2010 as a "new statewide technology coalition" formed to "support tech-friendly policy" in California on behalf of its member companies. From the beginning, the organization's small, otherwiseobscure corporate membership included an anchor tenant, so to speak: the Dallas-based AT\&T. The only Silicon Valley giant in the membership ranks was Cisco, the network equipment maker. Despite appearances, this was no trade association for California tech companies.

The founding director of the group, claiming to represent Silicon Valley in Sacramento, was a public relations consultant, Lane Kasselman. He left CALinnovates a few months later to join AT\&T fulltime as its Bay Area-based director of communications and public affairs (Kasselman, n.d.). His remit? To help get AT\&T's cell towers built across the region, in the face of tough regulatory and public challenges. As the Los Angeles Times reported in 2012, AT\&T had spent $\$ 47$ million on lobbying in California since 2000-more than double the next highest spender. From 2005 on, the company was spending $\$ 14,000$ a day on lobbying Golden State legislators (Goldmacher \& York, 2012, paras. 6, 38). 
CALinnovates's early positions hinted at a notably telco-friendly agenda. In late 2010, for example, the group released a poll that was probably commissioned by Cisco. ${ }^{3}$ Voters, CALinnovates reported, are "three times more likely to support a hands-off approach to the Internet and supportive of not adding regulations" (CALinnovates, 2010a, para. 11). Two months later, the group called for the FCC to take a "middle ground" on the "divisive" net neutrality issue, "dogged" by "extremist reactionary politics" (CALinnovates, 2010b, paras. 1, 3). ${ }^{4}$ In white papers, press releases, and sponsored events, CALinnovates endorsed "flexible" broadband pricing (CALinnovates, 2011c, para. 1), decried the "spectrum crunch" hobbling the U.S. mobile industry (CALinnovates, 2011a, para. 1), and backed the FCC's plans to remove the "proverbial 'red tape' from tower siting" (CALinnovates, 2011b, para. 1).

The group's public profile picked up dramatically with the arrival, in 2011, of a new executive director, Mike Montgomery, a veteran-like most of the group's staff and officers-of the state's Democratic Party political campaigns (CALinnovates, 2012a, p. 7; CALinnovates, n.d.). In the half decade since, Montgomery has taken his irreverent, industry-friendly voice to every corner of the Web, especially sites like the Huffington Post, Daily Kos, and Medium that let anyone post. ${ }^{5}$

Many of the CALinnovates posts and article placements were brazen publicity for AT\&T. In 2012, Montgomery issued a press release that opened with, "California's economic recovery will be bolstered by a recent announcement that AT\&T plans to invest an additional $\$ 14$ billion to expand and enhance its wired and wireless" broadband networks (CALinnovates, 2012b, para. 1). The release was filled with canned quotes from Montgomery, including the kicker: Investment like AT\&T's, said Montgomery, "will keep the U.S. and Silicon Valley ahead of the innovation curve" (para. 5). The CALinnovates release came just five days after AT\&T's own PR boast about the $\$ 14$ billion (AT\&T, 2012)-an announcement that coincided with the telco's FCC petition to ditch its common carrier obligations (Neuchterlein et al., 2012).

Just a few months earlier, Montgomery published a Huffington Post piece, "New FCC Commissioners a Breath of Fresh Air," reporting on a California visit that a pair of recent FCC appointees paid to "discuss ways to foster innovation and economic growth in tech industries, particularly telecommunications" (Montgomery, 2012, para. 1). Ajit Pai was one of the commissioners showered with praise (para. 3).

In early 2014, a federal court threw out the FCC's existing net neutrality rules, which had been established in 2010 (United States Court of Appeals, 2014). There was, suddenly, a policy free-for-all as

3 The CALinnovates poll was credited to "Zogby/463 Communications." 463 Communications, now called Vrge, is a public relations firm cofounded by Tom Galvin, Cisco's former corporate public relations head (Galvin, n.d.). Zogby Strategies lists Cisco "(2008-2010)" as a featured client: "Zogby has been retained several times both directly by Cisco and by its communications consultants (463 Communications, now known as Vrge)" (John Zogby Strategies, n.d.).

4 The group's executive director also met with FCC staff the same month to lobby for the FCC's compromise net neutrality position (Lehane, 2010).

${ }^{5}$ CALinnovates and Mike Montgomery have posted diaries to the liberal activism site Daily Kos at least 27 times since 2011 (Daily Kos, n.d.). 
an emboldened FCC moved to establish stricter rules on a much firmer regulatory basis. Over the next year, Verizon and AT\&T mobilized lawsuits, disinvestment threats, and poison-pill "compromise" proposals to prevent the Commission's Title II reclassification bid to define the companies' broadband Internet access and mobile wireless services as common carriers under the Telecommunications Act (a status that would require them to treat similar types of traffic in the same way-that is, without discrimination) (Craig, 2014; Knutson, 2015; Lopes, 2014).

That year, CALinnovates's budget nearly tripled, to $\$ 1.7$ million, and the group waged an aggressive campaign against the FCC (CALinnovates, 2015, p. 1). In the fall, Montgomery met with the legal advisors to the two FCC commissioners (Pai and Jessica Rosenworcel) (Montgomery, 2014a). In the meeting, Montgomery argued that Title II would "only reduce future investment in broadband" and, according to the filing, made the case for ISP-friendly paid-prioritization rules (pp. 1-2). ${ }^{6}$

The same day, CALinnovates submitted a lengthy white paper, commissioned from the Washington-based economics consulting firm NERA, to the FCC's official docket (Dippon \& Falk, 2014). ${ }^{7}$ The NERA paper argued that the FCC move to adopt strong net neutrality rules would undermine competition, lead to political gaming of the political process, and ultimately cause serious harm to consumers. Just two days later, CALinnovates filed its own 25-page comment to the docket (Montgomery, 2014b). Both documents made AT\&T-friendly arguments in great technical detail-though neither mentioned the company. ${ }^{8}$

Citing the group's campaign, the nonprofit investigative journalism outlet ProPublica published a story on CALinnovates (Faturechi, 2014). The article-which also exposed the cable and telecommunications industry front group Onward Internet-noted the surprise in Silicon Valley when CALinnovates came out swinging against the Title II plan. CALinnovates's stance, ProPublica observed, "gave the anti-reclassification camp a backer from within the tech community-a boon for one of CALinnovates' supporters, AT\&T" (Faturechi, 2014, para. 17). Montgomery refused to tell the reporter how much of the group's budget comes from AT\&T and brushed off concerns about disclosing ties to the telco in his various columns (paras. 19, 25).

\footnotetext{
6 Six weeks after the meeting with the FCC aides, Montgomery met with Pai himself to argue against Title II reclassification due to its effects on a "variety of industries in the broadband ecosystem" (Montgomery, 2014c, pp. 1-2).

7 The managing director of the Communications, Media and Internet Practice at the firm, Jeff Eisenach, was one of three FCC advisors for the Trump transition team (Romm, 2016). Eisenach, who has longstanding financial ties to the telecommunications industry, has also worked closely on many occasions with IJoC co-author Singer, as we detail below.

8 "CALinnovates is an organization," reads the comments document's first line, "that brings together stakeholders in the technology and startup communities with government leaders and policy makers" (Montgomery, 2014b, p. 1).
} 
CALinnovates, AT\&T, and the other telcos lost that fight when the net neutrality rules were adopted in early 2015 (FCC, 2015c). Montgomery, the same day, issued a statement-cum-threat with his trademark brio:

The loud sound coming from Washington today is resounding cheers from the lawyers, lobbyists and fundraising groups that will gain from today's FCC ruling for years to come. There will be a rush to the courtroom, which will take years to sort out. (Montgomery, 2015a, para. 2)

Taking to Medium a few months later, Montgomery called for Congress to enshrine net neutrality principles into law, though without admitting that any legislation would almost certainly gut Open Internet protections (Montgomery, 2015b). Nor did he mention that AT\&T filed a lawsuit to block the FCC rules (Brodkin, 2015). So his warning that a "court decision . . . could blow the whole thing to smithereens" comes off as a bit disingenuous (Montgomery, 2015b, para. 20).

CALinnovates continues to take AT\&T'S side in the hot-ticket issues before the FCC. The group filed official FCC comments in May 2016 opposing ISP privacy rules, repeatedly referencing the "startup community for whom we speak" (CALinnovates, 2016a, p. 2). Writing for Morning Consult in February 2017, Montgomery-describing himself as a "progressive Democrat"-chided the party's lawmakers for fixating on Internet freedom: More "fundamental issues must take precedence in these trying times," he declared (Montgomery, 2017c, para. 4). Just three days earlier, though, Montgomery had judged the topic important enough to issue yet another statement endorsing CALinnovates' "Third Way" approach (Montgomery, 2017a). And the FCC remains the group's singular fixation: CALinnovates has applauded nearly all of Pai's business-friendly decisions and regulatory rollbacks in the chairman's frenetic first months. "Ajit is a hardworking ass kicker who understands the economic and policy concerns of the broad tech sector," Montgomery said in a statement praising Pai's appointment (Montgomery, 2017b, para. 1).

Montgomery declined to provide a breakdown of CALinnovates's funding from AT\&T and its other members. What he and CALinnovates have done is lend the Texas telco's policy positions a patina of California progressivism. Posing as a "San Francisco-based high-tech advocacy group," CALinnovates appears to be a public relations Trojan horse, advancing the interests of a corporation hell-bent on winning rents from Silicon Valley firms and start-ups (CALinnovates, 2012b, para. 1). Readers of the IJoC "Curious Absence" paper could not have known any of that. The article's late-breaking disclosure makes no reference to the group's ties to the telecommunications industry, nor to its frenetic bid to reverse the key accomplishments of the FCC under Pai's predecessor, Tom Wheeler.

\section{Sins of Omission}

CALinnovates submitted the white paper, credited to Faulhaber and Singer, into the FCC's docket twice in the summer of 2016 (Faulhaber \& Singer, 2016a, 2016b). In his cover letter to the first of these filings, Montgomery decried the FCC's "recent divergence from policymaking grounded in facts and analysis" (Montgomery, 2016, p. 1). He zeroed in on the paper's discussion of "asymmetric regulation" of ISPs like AT\&T, urging (like the paper itself) the FCC to reconsider its ban on "paid prioritization" (pp. 1- 
2). The same day, CALinnovates distributed a press release extolling the "groundbreaking report by leading economists" (CALinnovates, 2016b, para. 1). The release quotes Montgomery: "We must get back to the practice of basing regulations on thorough analysis rather than populist rhetoric" (para. 3 ).

There was no mention-in the paper or the press release-that the paper's authors, Singer and Faulhaber, had played an active and extensive role before the FCC on the very regulatory issues they treat in their paper, which was picked up in the right-wing press, at sites like InsideSources (Giuseppe, 2016) and the American Enterprise Institute's Tech Policy Daily (Hurwitz, 2016). A week later, Senator John Thune (R-SD) invoked the paper at a congressional hearing, which he submitted to the official congressional record (Thune, 2016, paras. 18-19).

Just days after the publication of the $I J O C$ version in late March, Pai delivered a Hudson Institute speech on "The Importance of Economic Analysis at the FCC" (Pai, 2017b). He called out the original Faulhaber and Singer white paper twice, in remarks that closely tracked their claims. "But here's the rub," Pai told his audience. "The FCC's first-rate economists are not always used optimally" (p. 2). He went on to announce a new Office of Economics and Data, to gather together, and expand the influence of, economists around the agency (p. 5). ${ }^{9}$ "I'm delighted and excited," he said, "that the FCC is getting back into the game of economic analysis" (p. 6). A post on Pai's announcements from the tech industry-backed Technology Policy Institute, citing the IJOC article, was headlined, "Make Economics at the FCC Great Again" (Cecot, 2017).

In short, a paper commissioned by an industry-backed group was used by an industry-backed FCC chairman to support industry-backed policy changes. These private interests were cloaked in the rhetoric of academic neutrality in $I J O C$ and elsewhere.

In late April 2017, Pai announced his plan to roll back the 2015 Title II regulations, in a speech titled "The Future of Internet Freedom" (Pai, 2017c). It was fitting that Pai, in his case for dismantling net neutrality, cited research by Singer, the IJoC article's coauthor (see FCC, 2017a, pp. 15, 16, 35). Readers of the IJOC paper would have no way to know that in all the regulatory proceedings the authors hold up to scorn-and others since and before-they have submitted interventions on behalf of their consultancies and their clients. Their research and white papers have been appended to, or cited extensively in, submissions to the public record by industry players (e.g., AT\&T, Charter, Comcast, and Verizon on the telecom/ISP side and CBS, Disney, 20th Century Fox, Time Warner, and Viacom in the corporate media arena), trade associations (such as USTelecom, the Internet and Television Association [NCTA], and the National Association of Broadcasters), and think tanks (including the American Enterprise Institute and the

9 Pai reprised the OED announcement in a May 5, 2017, speech at the American Enterprise Institute (AEI) timed to celebrate his first 100 days as chairman (Pai, 2017a). "Speaking of doing things differently," he said to the group, "I have long been concerned that economists haven't been systematically incorporated into the FCC's policy work" (p. 5). He called out Jeff Eisenach, the NERA consultant, AEI visiting scholar, and Trump transition advisor: "And I'd be remiss if I didn't acknowledge the prior work done by Jeff Eisenach and others at AEI in providing the intellectual foundation for this office" (p. 5). 
Competitive Enterprise Institute). The authors, in other words, have been in the very thick of the action, which-as with the origins of their IJoC paper-they fail to disclose.

The paper's flaws, errors, and evidential cherry-picking make more sense in light of these omissions. The authors and their funders have a pony in the race.

\section{Bait and Switch}

The authors frame their paper as the story of the rise and fall of economic analysis at the FCC. In their account, the early FCC and its regulatory precursors in the 1910s and 1920s made decisions without regard for economic rationality. Broadcast spectrum was given away for free, they lament-with the lion's share ceded to the commercial broadcast networks. Despite growing discontent from economists such as Ronald Coase since the 1950s, the FCC continued to give away licenses for free until the introduction, in 1993, of spectrum auctions. It took decades, but economists had finally won influence over that specialized domain.

The authors' spectrum story, while accurate on its face, is notably partial. They portray the FCC's 1934 mandate to grant licenses in the "public interest" as hopelessly arbitrary. They ridicule 1950s-era resistance to the auction idea, from the agency's chief economist Dallas Smythe and some commissioners, as "feeble" and a reflection of regulatory capture, but without any fair consideration as to why the Commission took the approach that it had (Faulhaber et al., 2017, p. 1218; Taylor, 2013). They also leave out that broadcasters treated their licenses as de facto property anyway-with the accounting value of a license built into the worth of the companies that held them. Congress and the FCC had been "selling the air," as Thomas Streeter (1996) put it in his seminal book of that title, long before spectrum auctioning.

Setting these questions aside, the odd thing about Faulhaber, Singer, and Urschel's account is that they use the history of broadcasting regulation to set up an argument about telecommunications-the real focus of their paper after the first four pages. And if their case about broadcasting is dubious, it is worse when it comes to telecommunications. At least since the Interstate Commerce Commission assumed authority over telegraphs and telephones upon its creation in 1887-the first regulator in U.S. history, and really in the modern capitalist world-communications regulators have gathered and published copious statistics on the state of the industries they regulate. They have dealt with economic issues at length, including pricing, interconnection agreements between complementary and competing networks, common carriage, anticompetitive behavior, cross-subsidies, technical standards, and so on (Kahn, 1988). Nor do we see, for instance, any mention of the FCC's 1939 inquiry into AT\&T's stranglehold on not just the telephone business but also equipment manufacturing and even the Hollywood film industry. The telecommunications colossus had carved out a huge role for itself as a film equipment supplier and as the second-largest financier of films in the 1930s. AT\&T, anticipating regulatory intervention from the FCC's inquiry, dropped the film financing (Danielian, 1939). The episode is revealing as a demonstration that regulators' concern with the control or influence of content by common carriers has long been a key concern; there is nothing new, in other words, about regulators' recent attention to the issue. These are crucial omissions, because, first, a modicum of attention to regulatory history shows 
that economics has been there from the beginning, especially in the telecommunications arena; and, second, concerns over carriers' influence on content is a mainstay of regulatory politics.

In the authors' account, however, the history of common carriage-the precursor to what is now popularly referred to as net neutrality-is nowhere to be found. They also imply that economists only recently began their ascent to influence: "The evidence of any economic thinking in the FCC prior to the 1960 s is scant" (Faulhaber et al., 2017, p. 1218). The authors' story of hard-won prominence tracks standard episodes in the last 50 years of FCC telecom policy making, including the Carterphone case (1968), the introduction of long-distance competition (1977), the trilogy of Computer Inquiry reports between 1971 and 1986, the adoption of spectrum auctions (1993), and early attempts at Internet access regulation in the late 1990s and early 2000s. Economists steadily gained stature and policy sway over these decades, the authors write. The tide turned around 2010, as the agency-in a disastrous changesubstituted misinformed populism for the rational input of economics. Hence, the "curious absence of economic analysis" from the paper's title.

That claim is false, as we show. The authors should know better, since they are active participants in FCC policy matters.

\section{Dialing the Wrong Numbers}

The IJoC article opens with a now-famous 2016 remark by outgoing FCC chief economist Tim Brennan that his employer was an "economics-free zone"-an "insider's view," the authors add, "of how economics has been marginalized" at the agency (Faulhaber et al., 2017, p. 1214). The problem, however, is that Brennan has repeatedly walked back the comment. In one such effort, he wrote,

Hi. I'm the "economics-free zone" guy. . . . I'm the former chief economist of the Federal Communications Commission who used that line as part of a self-deprecating joke I told to defuse tensions at a small but contentious conference on the FCC's Open Internet Order. . . . The phrase . . . ended up in a Wall Street Journal op-ed and went somewhat viral, to my regret and chagrin. A panel of the D.C. Circuit Court of Appeals recently upheld the Open Internet Order by a 2-1 vote, but the dissenting judge, unfortunately from my perspective, made reference to what was part of an off-hand joke. . . I did not say it intending to slap the FCC. . . . I do disagree with the Order. But I do so in the belief that the FCC was pursuing its genuine view of the public interest. But now with allusions to this phrase in a judicial opinion, I want to set the record straight. (Brennan, 2016, p. 1, emphasis added)

Faulhaber, Singer, and Urschel (2017) nevertheless point to a precipitous drop-off in economic activity at the FCC. The agency's "internal economic think tank," they write, "produced 46 working papers that guided FCC decision making from the 1980s until 2012, when they mysteriously disappeared, only to be replaced with cursory 'fact sheets'" (p. 1215). They also assert that 2015 "appears to mark the nadir of economic influence at the agency," since the Commission hosted just four economic seminars that yearwell below the average of 16 per year from 2010 to 2014 (p. 1215). 
There are several problems with their claims. For one, the authors have the numbers wrong. For instance, there were 86 white papers published between 1980 and 2012, not 46, as they state (FCC, n.d. [WP]). Moreover, if the "peak of economic analysis" occurred in the 1990s (Faulhaber et al., 2017, p. 1220), why were only six white papers published that decade? Fifty-five of those 86 white papers were issued after 2000; 33 in just a single year, 2003. And we should not take quantity as a proxy for quality: The vast majority of those papers in 2003 appear to have been intended mainly to bolster the Republicanled FCC's hotly contested case to relax media ownership and concentration rules. Yes, there are real gems among the three decades of agency white papers, but many were flimsy efforts that betrayed political motives (FCC, n.d. [WP]; see also Napoli, 2008).

More importantly, the authors do not mention the alternatives to the white paper series adopted by the agency since: seminars, workshops, working groups, and roundtables. The Economic Seminars, for instance, were established by the Obama administration's first FCC chair, Julius Genachowski (20092013), shortly before the working paper series was dropped. It is true that the number of such seminars plunged in 2015, though there were five, not four, as the authors mistakenly claim (FCC, n.d. [Seminars]). The authors, more importantly, fail to note that the agency hosted 19 seminars last yearwell above the five-year average. So 2015's low seminar count appears to be a cherry-picked anomaly that hardly supports the authors' sweeping claim. A far more plausible explanation for the one-year dip is that 2015 was an unusually busy year for the FCC, with the Internet proceedings and a pair of blockbuster merger and acquisition reviews (as addressed below) (see Bring et al., 2015; Carare et al., 2016; Sallet, 2015).

Also consider, for example, that if the FCC is so devoid of economic competence, then we would expect it to have few economists in-house and to compare poorly to other regulatory agencies. The authors do not address this point, but it is clear that they believe the number is too low. Pai (2017b), in his recent speech citing the authors' paper, observed that the Federal Trade Commission's "Bureau of Economics has nearly eighty Ph.D.-level economists," with an implied contrast to his FCC. The agency, however, has about 60 economists on staff, with roughly $80 \%$ holding an economics PhD-figures that have held steady over time. ${ }^{10}$ The Commission, moreover, hires a chief economist from the academic world for one- to two-year stints to provide direction and oversight on key issues. One of the IJoC paper's authors, Gerald R. Faulhaber, filled that role in 2001 and 2002, so the authors are fully aware of this tradition. In addition, five of the Commission's seven bureaus have a chief economist. For big files like the Open Internet Order or proposed megamergers, the FCC assembles a team of economists, engineers, lawyers, and others to develop its analysis and decision. The agency also retains academic and commercial consultants, convenes working groups, holds seminars, and so on to help get a handle on the complex issues at stake in these files. With large mergers and acquisitions, moreover, the Commission works hand in glove with the Department of Justice's Economic Analysis Group-its crack team of mainly $\mathrm{PhD}$ economists from top U.S. universities who specialize in antitrust, "network economics," and the media

10 Pai's comparison of the FCC to the FTC is, moreover, flawed. The FTC's reach covers the whole U.S. economy, while the FCC's remit covers just telecommunications, Internet access, television, and radiokey areas of the economy, to be sure, but only a slice of it. In other words, pound for pound, the FCC's 50-odd PhD-level economists stack up well with the FTC. 
industries (more on this below) (FCC, 2015c; U.S. Department of Justice, 2017). To be sure, the economists are outnumbered by lawyers and engineers, but they are still a prominent and integral part of the process. Even though the authors do not address any of these points, they are well aware of them since Singer and Faulhaber are regular participants in FCC matters.

Of course, the mere presence of economists does not mean that the FCC, or any regulator, will make good policy. Indeed, we contend that other disciplines, including communication, history, and sociology, should be consulted with far more regularity than is currently the case. But as a point of fact, the IJoC paper's claim that the FCC is an "economics-free zone" is simply untrue.

\section{Elephants in the Room}

In addition to its fairly deep roster of in-house economists, and its range of outside consultants (including from the Department of Justice), the FCC has a habit of convening advisory committees, working groups, workshops, and so on that bring even more intellectual heft-and cross-cutting views-to the table. This was especially true in the context of the Open Internet proceedings. Take, for example, the agency's 2014 Economics of Broadband roundtable. ${ }^{11}$ The discussion was chaired by Tim Brennan, the FCC chief economist of "economics-free zone" fame, and included a half dozen top-flight Internet and media economists-including $\mathrm{Hal}$ Singer, the IJOC paper's coauthor. As Brennan said at the outset of the

${ }^{11}$ In addition to the Economics of Broadband Roundtable, the FCC established an Open Internet Advisory Committee (OIAC) that convened several working groups, workshops, and a half dozen roundtables designed to examine net neutrality (FCC, 2014b, 2016e). Jonathan Zittrain, a Harvard law professor, chaired the OIAC, and the committee's co-chair was Internet "founding figure" David Clark from MIT. A dozen and a half others from venture capital firms, Internet equipment makers, ISPs, the television and film business, and nonprofit groups rounded out its membership. Shane Greenstein, an economist then at Northwestern University and now at Harvard Business School and author of How the Internet Became Commercial (2015), was also heavily involved. His stints as advisor to industry as well as to the Department of Commerce in the Bush administration and the Conference Board during the Obama administration, respectively, suggest that he was well suited for his role as the FCC's special advisor on the economics of broadband Internet. He also chaired the Economic Impact of Open Internet Frameworks Working Group and served as special economic consultant for the Commission's review of Comcast's bid to acquire Time Warner Cable (see below). Reports on data caps (FCC, 2013b) and Internet access pricing (FCC, 2013b), as well as the OIAC's Annual Report (FCC, 2013a), also stand as testimony to the enormous attention the FCC gave to economic issues in the run-up to the Open Internet Order. Moreover, Singer and Faulhaber were party to many of these events, which they do not mention (FCC, 2014b, 2014d). The latter event brought together a who's who list of industry, think tanks, and academia representatives with well-known-and cross-cutting-views on the topic. The FCC's top brass, including Robert Cannon, whose authoritative account of the FCC's trilogy of Computer Inquiries helps us grasp how we got from the first melding of computing and telecommunications in the $1950 \mathrm{~s}$ to the broadband Internet of the 21st century, were there, too (Cannon, 2003; FCC, 2014a, 2014c). All of this is conspicuously absent from the IJoC paper. 
roundtable, "I don't think it would be possible to get a better panel than this" (FCC, 2014d, 10-minute mark).

Singer and Brennan were joined by a half dozen other Internet and media economists: Jonathan Levy, Jonathan Baker, Nicholas Economides, Thomas Hazlett, Christian Hogendorn, and John Mayo. A quick rundown of this who's who list of players bears directly on the claims of the IJoC paper and its predecessor versions.

First, Brennan introduced his FCC colleague, Jonathan Levy, the agency's long-standing deputy chief economist. At the roundtable, Brennan introduced Levy as

one of the leading media economic experts . . . that you can find. A great example of the really high-quality of economics that you can find here. One of the great pleasures of being the Chief Economist here is getting to work with people like John. (FCC, 2014d, 10-minute mark)

Then Brennan introduced Jonathan Baker, who served as the FCC chief economist from 2009 to 2011, as the second, ill-fated version of the Open Internet principles was put into the place. ${ }^{12}$ With a law degree from Harvard and an economics PhD from Stanford, Baker had also served as director of the FTC's Bureau of Economics and as senior economist on the President's Council of Economic Advisors. As Brennan stated, Baker "is one of the leading go-to people in DC and anywhere on anti-trust laws and issues, most recently on exclusionary conduct but really on a whole lot of things that are germane here." At the roundtable, Baker stressed that he was not working for clients or otherwise involved in the Open Internet proceeding. He also argued that strong ex ante net neutrality rules were needed and (unlike Singer and Faulhaber) that antitrust law and economic approaches cannot adequately address the issues (26-minute mark). He was also clear that the "costs of FCC rules are likely to be small." This was because the cut and thrust of such an approach had already been in effect due to the earlier Open Internet principles and the conditions placed on Comcast in return for the FCC's blessing of the cable/ISP giant's NBC Universal acquisition. "Sketch the benefits and costs," Baker said, "and I conclude that the rules . . . would pass any sensible cost-benefit test even with concerns about mobile data and interconnection" (28-minute, 30second mark). Baker's points are widely known and contradict the $I J 0 C$ authors' central claim about costbenefit analyses at the FCC (Baker, 2013; Baker et al., 2011). That Baker also sees common carrier regulation along the lines that the FCC ultimately adopted as the right tool for the job-and consistent with the 2014 Verizon decision-also clashes with the authors' indictment of the "irrationality" of common carriage/net neutrality regulations.

After Baker, Brennan introduced Nicholas Economides, a professor of economics at New York University's Stern School of Business:

\footnotetext{
12 It's important to note that this was not because the FCC could not adopt them, as the DC Circuit Court stated in its 2014 Verizon ruling, but because the Commission had chosen the wrong tool for the job.
} 
If anyone could be said to have created the field of network economics as a formal area of research, it would be Nick Economides. He is the leading researcher applying economic theory to network pricing, vertical integration, network neutrality, compatibility issues, he is really the tops. (FCC, 2014d, 11-minute mark)

Economides made it clear that he, too, sees common carrier rules as the right tool for broadband Internet access regulation. He also immediately disclosed that he was not working for anyone on the Open Internet process.

Christiaan Hogendorn was the "new kid on the block," Brennan quipped, and an associate professor of economics at Wesleyan University. Hogendorn, a specialist on pricing issues, vertical integration, and net neutrality, also addressed how people use, think about, and experience the Internet. The Internet, he said, is unique for a pair of reasons: First, it is a general-purpose technology that supports a wide and diverse range of economic and social activity; and, second, its value for people grows the more people use it ("network effects"). These features make the Internet an "innovation spawning" ground with lots of spillover effects. As a result, Hogendorn said, economists' usual approach of considering individual buyers and sellers, prices, and utilitarian calculations of the pleasure and pain of consuming one thing over another do not get at the crux of things. We need, he said, a different approach to the economics of the Internet, and its regulation (43-minute mark). Like Baker and Economides, Hogendorn stated that he had no financial entanglements with organizations lobbying on the issues, and like them, he, too, saw the virtues of reclassifying ISPs as common carriers.

Then there was Thomas Hazlett, the FCC's chief economist in 1991 and 1992, and now an endowed professor of economics at Clemson University. Before Clemson, Hazlett spent years at George Mason University, where he carved out a strong reputation as an expert in spectrum policy and competition and as a stern critic of regulation and the FCC. He argued that regulating the broadband Internet access providers as common carriers was a bad idea. Hazlett was followed by another well-known regulatory economist, John Mayo-a professor of economics at Georgetown's McDonough School of Business. From Mayo's perspective, the costs of common carriage regulation would greatly exceed any benefits. Unfortunately, he argued, regulation tends to get buffeted about by the ideological winds of the day, with network neutrality as a lamentable case in point. Finally, there was Hal Singer himself, adjunct professor at Georgetown's McDonough School of Business, principal of Economists Incorporated, and senior fellow at the Progressive Policy Institute, a think tank associated with former president Bill Clinton.

It is telling that-unlike the roundtable's first three participants-Hazlett, Mayo, and Singer had direct stakes in the Open Internet proceeding on behalf of think tanks and industry clients (see below). But none of them disclosed this.

Our goal is not to review the evidence cited by these roundtable participants, nor to question their well-known contributions to the economics of broadband, nor to adjudicate between their competing views. Our point is to show that economists-even two of the three IJoC authors-took part in the FCC's deliberations in droves. 
In fact, many of these same economists, including Faulhaber and Singer, were all over the FCC's final Open Internet Order (FCC, 2015c). Singer, for example, coauthored an anti-Title II paper with the Brookings Institution's Robert Litan that was submitted to the official docket by the Singer-linked Progressive Policy Institute, which also contributed additional materials to the proceeding (Litan \& Singer, 2014; Progressive Policy Institute, 2014). The Georgetown University Center for Business and Public Policy (Balto, 2015, pp. iv, 8, 14) submission to the proceeding also cites Singer's work, as does the American Cable Association (2014) filing. Singer and Faulhaber's research and writings, including the CALinnovates white paper, are cited extensively in the Open Internet record and related matters by major industry players, trade groups, and think tanks (FCC, n.d. [EFCS]). ${ }^{13}$ They are frequent signatories to open letters issued by economists addressed to the FCC and to courts hearing industry appeals (e.g., Atkinson, 2013; Balto, 2015; FCC, 2014e). The authors, in short, are prominent nodes in a sprawling scholar-lobbyist network that arguably flooded the marketplace of ideas with their well-funded fight against Title II reclassification (Lipton, Confessore, \& Williams, 2016).

By now it is hardly surprising to learn that Pai also cited Singer and others in the scholar-lobbyist network in his strident dissent to the 2015 Open Internet Order (FCC, 2015c, p. 329, fn. 60). As we have seen, he continues to reference Singer in speeches and policy documents that make the case for dismantling net neutrality and common carriage (Pai, 2017a, 2017b, 2017c). Many of these citations point to Singer's finding that Title II reclassification caused a slowdown in ISP broadband investment-a claim repeated in the CALinnovates/IJoC paper (Faulhaber et al., 2017, p. 1228). The claim is hotly contested by many other observers, but the most authoritative data set, from the U.S. Census Bureau, shows a slight uptick in investment in the latest year for which data are available, 2015 (FCC, 2017a, pp. 15-16, 35; U.S. Census Bureau, 2017a). Ultimately, it is probably still too early to determine the rules' effects on investment, but early indications suggest a minor impact, whatever the direction.

Over the course of many pages and at several points, the agency's official Open Internet Order reviewed a wide body of data, studies, and other evidence submitted by consultants (e.g., NERA, WiK Consult, and Copenhagen Economics); industry groups (e.g., USTelecom, NCTA, and the Internet Association); individual ISPs (e.g., AT\&T, Comcast, and Verizon); academics (e.g., Singer, Litan, Marcus, Mayo, Hassett, and Shapiro); financial analysts, banks, and venture capital funds (e.g., JP Morgan, Bernstein Research, and SNL Kagan); and public interest groups (e.g., Free Press and Public Knowledge). Studies from the National Economic Council and the U.S. Office of Science and Technology Policy were also reviewed. The upshot was, essentially, that the doomsday scenarios painted by the foes of common carrier rules were overwrought and that-taking a wider lens-the effect of Title II was likely to be positive (FCC, 2015c, pp. 25-54, 193-199). Pai disagreed, and sided with the naysayers (FCC, 2015c, p. 327). In its own review, the DC Circuit Court of Appeals found the evidence mixed but concluded that the FCC had made "a rational connection between the facts found and the choice it made'" (United States Court of Appeals, 2016, p. 18). Reasonable disagreement on these points is possible, of course, but the idea that the FCC issued its Open Internet Order without regard to economics is simply inaccurate.

13 See the FCC's Electronic Comment Filing System for the proceeding number (14-28) and author keyword search (https://www.fcc.gov/ecfs/). 
The same basic point can be made across the other main dimensions of economic analysis central to debates over the "future of the Internet": pricing, interconnection, paid priority, subscriber demand, the scope of the FCC's mandate, the cost of regulation, transparency and disclosure requirements, and so on. On each issue, the official record is filled with defensible economic analysis (see, e.g., FCC, 2015c, paras. $126,198,279,419,501,502)$. As the Open Internet Order notes, the agency's conclusions "rest upon a well-established body of economic literature, including Commission staff working papers" (p. 55). The DC Circuit Court of Appeal agreed.

In the face of mixed evidence, the outcomes ultimately turned on political and normative grounds. A key question was where power and control over the creation and consumption of expression should rest. Should the ISPs hold that power alone, or should control be dispersed as widely into as many hands, devices, and creators of content, apps, and services as possible? And that question, in turn, raises free speech issues. In other words, the question was (and is) whether free speech rights should be reassigned to mobile phone companies and ISPs, as Pai has proposed. Or should those rights remain with people and publishers? The FCC and DC Circuit Court disposed of telecoms operators' and ISPs' claims that common carriage rules deny them their free speech rights in short order (FCC, 2015c, pp. 268, 273; United States Court of Appeals, 2016, p. 106). Pai's recent U-turn, however, has reopened the issue with clear bias in favor of the ISPs' and mobile phone companies' speech rights claims. If that interpretation prevails-as outlined in Pai's Notice of Proposed Rule Making-free speech rights would extend to telephone companies and ISPs for the first time in U.S. history (FCC, 2017a, p. 33).

At the core of this profoundly important issue is not just the conceptual distinction between carriers and speakers/publishers but questions about vertical integration, market power, and ISP incentives and capacity to act as gatekeepers. Once again, the FCC canvassed the positions before it, as well as the published literature of the past 30 years, including by its own staff, to identify both wellestablished positions and fresh views (FCC, 2015c, pp. 28-50; see also FCC, 2017b, pp. 6-8, fn. 19-29). The basic takeaway, for our purposes, is that economic analysis-including work by Faulhaber and Singer-has been very well represented in these debates.

Crucially, the FCC took these lessons as the basis for creating a broad spectrum of approaches to deal with the issue of gatekeeping power. At one end, the agency adopted a priori bright-line rules against paid prioritization, blocking and throttling (a "rule of law," "per se" approach, as it is known in U.S. regulatory parlance). At the other end, the FCC committed to address the issues as they evolve in concrete cases, with an emphasis on two key issues: first, ISP interconnection, on one side, and the content distribution networks of Internet giants like Google, Facebook, and Netflix, on the other (the heart of the tussle between Comcast and Netflix in 2014, for example). The second issue is the practice of zerorating. ${ }^{14}$ The FCC's approach to both matters will rely on case-by-case evaluations so that the lessons of

14 Zero-rating is when ISPs and mobile phone operators do not count the data used for some content, applications, and services, while everything else that a person uses broadband Internet or mobile phone for are counted against his or her data caps. The Wheeler FCC had identified concerns with AT\&T allowing its mobile wireless subscribers to watch unlimited DirecTV television content without it counting toward their data caps, while all other sources of video (and content, apps, and services) would, and with 
experience can inform hard-to-predict conditions in the future. A key reason that the debates over these issues have been so heated and intractable is that they track debates on economic concentration and antitrust that go back to the late 19th and early 20th centuries (Hovenkamp, 2008; Sklar, 1988). The Obama-era FCC's adoption of a mixed ex ante ("rule-of-law") and ex post ("rule-of-reason") approach is similar to the strategy adopted by Canadian and European regulators. In contrast, the Telecom Regulatory Authority of India (2016) in 2015 slammed the gate shut for a five-year period on zero-rating on the grounds that it is a small regulator in a big and relatively poor country, with insufficient resources to take on global behemoths such as Vodafone, Facebook, Google, or Tata every time they put a novel twist on an otherwise standard gimmick-an endless game of regulatory whack-a-mole with those whose pockets are deep enough to play it forever. The FCC (and Canada and EU28) are not as resource-constrained and can afford to take the far more time-consuming, resource-intensive, case-by-case, "rule-of-reason" approach on issues like zero-rating and interconnection.

The point is that the FCC, in its 2015 Open Internet Order, adopted a mixed response to the relevant regulatory challenges. On fast-changing secondary matters like interconnection, the agency promised to take the case-by-case approach, despite the risk of regulatory whack-a-mole with deeppocketed industry players. On the core question of common carriage, however, the agency opted for bright-line rules. The DC Circuit's majority ruling endorsed the FCC's decision: "The Commission . . . convincingly detailed how broadband providers' position in the market gives them the economic power to restrict edge-provider traffic and charge for the services they furnish edge providers" (United States Court of Appeals, 2016, p. 18).

\section{Mergers and Acquisitions}

The depth of economists' input into the Open Internet Order was nothing exceptional. Economic analysis also played a pivotal role in the FCC's review of several blockbuster mergers and acquisitions in the last half decade-precisely the period when Faulhaber et al. say economists were getting sidelined. Three cases exemplify the point: Comcast's failed bid to take over Time Warner Cable in 2015, Comcast's acquisition of NBC Universal four years earlier, and AT\&T's bid to acquire T-Mobile in 2011. We focus on just the first case for reasons of space, but the lessons apply to all three (FCC, n.d. [M\&As]; Sallet, 2015). Comcast's bid for Time Warner Cable aimed to bring together the two largest broadband Internet access providers as well as the biggest and fourth-largest multichannel video program distributors in the United States (FCC, 2015d). Combining forces, a large team of economists from the FCC's staff and the Department of Justice's Economic Analysis Group was assembled to address the merger (FCC, 2015a; U.S. Department of Justice, 2016).

Verizon's FreeBee "sponsored" data program. Pai, however, unilaterally waived away the proposed new zero-rating guidelines adopted in response shortly after becoming the new chair (FCC, 2017c). India banned the practice outright. The European Union and Canada have adopted restrictive case-by-case reviews that allow potential exceptions under very precise conditions (Klass, Winseck, Nanni, \& Mckelvey, 2016). 
Several academic and consulting economists were also retained, including Bill Rogerson (Northwestern University), Shane Greenstein (Harvard Business School), and Brennan himself. (Indeed, in his capacity as chief economist, Brennan had sought to steer the Open Internet docket that was taking place at roughly the same time, but Wheeler decided against switching him from the one role to the other). However, Brennan's roundtable chair and other significant roles in the Open Internet review show that his views were considered, even if the adopted rules were not his preferred outcome. David Waterman, an Indiana University economist who has conducted extensive research on media and telecommunication regulatory issues, also helped steer the Commission's review of the proposed deal. Waterman, a specialist on cable and ISP vertical integration as well as traditional and over-the-top Internet-based television, was the FCC's chief economist in 2015 (Bring et al., 2015; Sallet, 2015).

Comcast, Time Warner Cable, and other industry stakeholders, including Netflix, Cogent, DISH, and the American Cable Association, also brought in their own economists. But economists from public interest and consumer groups like Free Press, Public Knowledge, and the Consumer Federation of America (CFA) were notably absent from the workshop, even though, for instance, the CFA's Mark Cooper is renowned for his tenacity and skill as an economist and researcher (Noam, 2009, p. 21). The FCC convened a workshop in early 2015 attended by 23 economists, the 368-page transcript of which flies in the face of claims that economists have been "conspicuously absent" from the table at the FCC in recent years (FCC, 2015a, 2015b).

After 14 months, the FCC and Department of Justice's "transaction team" had built a voluminous public record and drafted a preliminary report on the Comcast/Time Warner Cable deal that raised significant concerns-enough, in fact, that Comcast and Time Warner Cable decided to walk away from the merger. A similar dynamic has played out in other recent cases, too. Four years earlier, for example, the Department of Justice and FCC's review of AT\&T's bid to acquire T-Mobile also raised red flags. Unsurprisingly, economic analysis formed a cornerstone of the administration's analysis of that deal as well, which featured a study focused on concentration levels, subscriber choice, and pricing in 100 U.S. cities. With a finding that competition would be hobbled in nearly all these cities, the regulators were ready to spike the deal-though again the companies folded on their own (Sallet, 2015; U.S. Department of Justice, 2011).

Comcast's successful takeover of NBC Universal in 2011 seems to offer a very different lesson. However, the conditions imposed on Comcast in return for the regulators' blessing actually constrained its ability to use its market power to stymie the growth of competitors like Netflix and Amazon Primeservices, of course, that need not just Comcast's "pipes" but also access to the enormous catalog of NBC Universal programming that Comcast had just acquired. Charter Communications' acquisition of Time Warner Cable in 2016 played out similarly, as the "New Charter" was banned from imposing any data caps for seven years to prevent anticompetitive control over its pipes (FCC, 2016a).

Outside the merger review process, the FCC has conducted a series of studies that have consistently shown, for nearly a decade, that concentration levels in mobile wireless and broadband access markets are "astonishingly high," as Eli Noam (2016) observes (see pp. 25, 1307-1316). The FCC's latest report on the mobile wireless markets, for example, found that concentration rates are sky-high-and 
rising-based on two commonly used measures (i.e., concentration ratios and the Herfindahl-Hirschmann Index) (FCC, 2016c, paras. 19-22). Of course, the issues are not this simple, but the fact that the Commission's research lines up well with independent studies that point in a similar direction incenses its critics-including Pai, Faulhaber, Singer, and others (see, e.g., Delp \& Mayo, 2016; Faulhaber, Hahn, \& Singer, 2012).

The stiffer regulatory line that Pai and the authors oppose, however, has had measurable positive effects that should not be ignored. Consider, for instance, the improvements in the accessibility, affordability, and adoption of mobile wireless services over the past half decade or so. As a result, the United States no longer languishes at the bottom of the "international league tables" alongside Mexico and Turkey. Instead, the United States has consistently ranked in the top quarter of 40 European Union and Organisation for Economic Co-operation and Development countries for several years. Canada, in contrast, still lags behind on most of these measures due to a lack of consistent resolve (see, e.g., the progression of the United States along these lines in FCC, 2016b, 2016c; Organisation for Economic Co-operation and Development, 2017).

Nothing riles the friends of industry more than this run of events, and they have done everything they can to discredit anyone with the temerity to stand up against incumbent industry players. This, we suspect, is what's really behind the Faulhaber, Singer, and Urschel criticisms. And having lost their battles before regulators, the courts, and the public, they are now trying to fight back and win the day, resorting to unsubstantiated charges of economic illiteracy. We also sense that they are unsettled by the decline of the Chicago School of Economics, which has come under growing strain after a 40-year reign of orthodoxy in telecommunications economics and regulatory circles. The fact is that long-standing debates in modern economic thought between rule-of-law approaches to market power and the rule-of-reason alternative are once again cresting. This battle of ideas, stretching back to the late 19th century, is buried in the authors' frequent appeals to a singular "economics" perspective. ${ }^{15}$

\section{Lost Keys and Lampposts}

Faulhaber, Singer, and Urschel (2017) repeatedly take the FCC to task for not conducting costbenefit analyses. The following paragraph captures the crux of their case:

Recall that when the FCC issued its 2015 [Open Internet Order], it issued a separate statement noting that it had no obligation to perform a cost-benefit analysis. Imposing such a constraint on the FCC would ensure that economics plays a vital role in future FCC decision making. There is no reason why the Department of Labor (an executive agency), the Environmental Protection Agency (an independent agency), or the Consumer Financial Protection Bureau (an independent regulatory agency) should be held to a rigorous cost-benefit analysis, while the FCC is free to embrace populism as its

${ }^{15}$ For a fuller view of these contending schools of thought and some of the mounting challenges to the Chicago School in recent years, see Adams (1954); Hovenkamp (2008); Kahn (1954, 1988); Noam (2016); Sallet (2015); Sklar (1988); and Stucke and Grunes (2016). 
guiding principle. The tech industries under the FCC's domain are equally if not more important to the U.S. economy. (p. 1229, emphasis added)

What they say about the FCC's short statement is true (FCC, 2016d), but the rest of the passage is highly misleading, and in several ways plain wrong. That is because no independent regulatory agencies except the one they identify (the Consumer Financial Protection Bureau [CFPB]), does the kind of cost-benefit analysis that they claim the FCC neglects. Indeed, there are 19 federal independent regulatory agencies, and none of them file the kinds of cost-benefit analysis that Faulhaber et al. call for, except the CFPB. Yet they seem to imply that somehow the CFPB stands in for them all. It does not.

The CFPB was one of many new financial-sector regulators created in 2010 and 2011 in response to the financial crisis of 2008. Given the extreme sensitivity of the public to the government's bailout of the banks and financial markets, the CFPB was intentionally put on a short leash. With that single exception, only executive agencies and independent agencies must file cost-benefit analysis reports to the Office of Management and Budget and its Office of Information and Regulatory Affairs (Breger \& Edles, 2015, p. 188; Copeland, 2013; Sunstein, 2013). The FCC reports to Congress-just like every other independent regulatory agency.

Measuring the FCC against executive-level agencies, in short, is an apples-and-oranges comparison. Conservative economists and politicians have been pushing and prodding to make independent regulatory agencies follow stricter rules of economic analysis along the lines the authors propose since the first Reagan administration in the early 1980s, but these calls have been steadfastly rejected. Why? Because doing so would place them too close to political masters in the executive branch and undercut the very principle that defines them: independence (Breger \& Edles, 2015, pp. 183-186; Copeland, 2013). In other words, Faulhaber et al. are pursuing a 40-year-old political project that aims to put the FCC on a shorter leash, but without saying so. Worse, Pai has taken their cue to underwrite his call for a new Office of Economics and Data. Like the authors, Pai hides behind a veneer of academic neutrality-who could possibly oppose accountability and good economics?-to justify his broader agenda of industry-friendly broadband and mobile wireless regulation. ${ }^{16}$

The irony, however, is that the FCC appears to have been doing more economics and accountability reporting in recent years, not less. We already mentioned the many working groups, workshops, roundtables, and transaction analyses hosted by the Commission. Every year since 2002, except for 2005, the chief economist and other staff have issued a review, "The Year in Economics at the FCC" (see, e.g., Baker et al., 2011; Bring et al., 2015). The FCC has been publishing the data sets behind its major reports for the past half decade or so as well as detailed maps that outline access, pricing, and market structure conditions by census areas across the United States since 2011. The number of reports released during Wheeler's term (11.5) was lower than in either Genachowski's (13.5), Martin's (15), or

${ }^{16}$ It is important to note that both Faulhaber et al. and Pai mention that independent regulatory agencies are not required to use cost benefit analysis, but they do so in passing-the former at the very end of their article, and otherwise obscured by a line of argument and innuendo that strongly implies that the FCC has been exceptionally negligent for not having done so. 
Powell's (12) terms, but not far off their marks and above the average since 1996 (10.5) (FCC, n.d. [Reports \& Research]). The FCC is also held in high regard by other regulators, including the Canadian Radio-television and Telecommunications Commission, Ofcom in the United Kingdom, the Body of European Regulators for Electronic Communications, and the Telecom Regulatory Authority of India, with all of them meeting regularly to swap knowledge, supported by statisticians from national statistical agencies, the Organisation for Economic Co-operation and Development, the International Telecommunications Union, and, of course, academic economists and other scholars.

Finally, people who work at the FCC say that while cost-benefit-analysis had been hit or miss in the past, after the adoption of new guidelines by Genachowski in 2011, there has been "substantial interaction and consultation with economists . . . about how such studies should be done" (Copeland, 2013, p. 103). According to Copeland, the biggest obstacle to FCC efforts in this regard is not a lack of authority or willingness on its part, but the fact that much of the information it obtains from the industry players that it regulates is shrouded in a thicket of nondisclosure agreements and proprietary limits ( $p$. 105). Presumably Faulhaber et al. (2017) know all of this, too, given that they also cite Copeland's study (p. 1229).

\section{Conclusion}

The core claim woven throughout Faulhaber, Singer, and Urschel's (2017) argument-that the disinterested expertise of economists has given way to a reckless and misinformed mob-is troubling, especially in light of our observations. The authors contrast the salutary respect granted to economists up through the first decade of the 21st century with the FCC's "populist period" since (p. 1223). Yes, consumer groups and protesters had tried to disrupt reasonable policy making before, the authors write with barely concealed contempt, but the FCC, thankfully, "gave those efforts short shrift" (p. 1222).

That all changed, however, when the FCC sidelined economists in its bid to reclassify broadband Internet access as a Title II common carrier service in 2015-a decision, the authors say, that sunk the "elegant, light-touch solution" that "smart lawyers at the FCC"-"quarantined from political forces"-had drafted (pp. 1224-1225). Blame, in the authors' words, lay with "John Oliver and four million angry letters ostensibly submitted to the FCC" (p. 1225). Those letters invoking the "esoteric language" of Title II authority could not have been legitimate, they added: "a great many likely were form letters generated by public interest groups clamoring for Title II-based solutions" (p. 1225). The FCC buckled to a populist upsurge, basing its Title II decision on the "casual empiricism of an advocacy group that operates"-unlike the authors and the discipline of economics-"outside of the constraints of academic reputations" (p. 1225).

The authors' story-of technocratic expertise outgunned by an unruly, ignorant rabble-is audacious, as we detail above. ${ }^{17}$ Set aside the article's claim, endlessly invoked, to speak for an entire discipline (the "teaching of economics," "from an economic perspective," "serious economic analysis") with

17 The claim also overstates the influence of public comments on FCC policy making, which are, and have been for decades, routinely ignored (see Holman \& McGregor, 2001; McGregor, 2006). 
far more internal heterogeneity on these questions than they let on. Set aside, too, the fact that apparently neutral phrases and practices, such as "procompetitive," "capital investment," and "costbenefit analysis," are marinated in contestable value judgments. The smuggled-in assumption is that what counts as good policy is something like market efficiency. That is a defensible claim, but the key point is that it is irredeemably value-laden. Net neutrality advocates are invoking values too: that a healthy democracy, and a level economic playing field, depend on an open, nondiscriminatory Internet. The authors do not get to cloak their value judgments-and theirs alone-in the language of academic neutrality. The whole thrust of their argument suggests that the federal courts' landmark 1966 United Church of Christ $v$. FCC decision that forced the agency to open participation to the public is due for a reset-to how things were a half century ago, when public "input" meant talismanic invocation of "the public interest" by economists, business interests, engineers, and FCC commissioners with their own stakes in the outcome (Office of Communication v. FCC, 1966).

The expert/populism frame, more to the point, papers over the fact that private interests paid for the article. AT\&T and the other ISPs desperately want to reverse the common carrier designation-to see net neutrality's demise-in order to open up new revenue streams and, more broadly, to establish a network-centric model of control in which they are in charge of who gets to use their "pipes" to say what to whom on what terms. They want telecommunications and broadband Internet access treated like publishers rather than common carriers. If they get their way, they will have the freedom, like publishers, to exercise editorial control over the messages, content, applications, and services flowing across their systems. For nearly 40 years, going back to the post-AT\&T breakup era, they have waged an aggressive, multifront war to win those powers. That is their prerogative. But pincer-like campaigns to enlist AstroTurf groups and commissioned white papers operate by stealth (Jansen, 2017). They are parasitic on thirdparty credibility, like grassroots activism or-in this case-the legitimacy of academic research.

A galling irony of the authors' populism charge is that Trump's brand of bait-and-switch populism has brought AT\&T, Verizon, Comcast, and other net neutrality opponents to the edge of deliverance. Ajit Pai's chairmanship-his fast-moving effort to roll back Title II-is a direct product of unbridled populism. ${ }^{18}$

The "Curious Absence" case, finally, raises a broader concern. The history of media-industry underwriting for communication research is as old as the organized field itself. Magazine publishers, CBS, and the National Association of Broadcasters funded a large share of midcentury media research. The scholars who took those dollars, such as Paul Lazarsfeld, were not just shills for the industry. The studies they produced were motivated by genuine intellectual questions, with important and complex results. But their most prominent, public-facing work, especially in the late 1940s and 1950s, concluded that media effects are happily negligible. It is no surprise that broadcasters used this evidence to ward off congressional and FCC scrutiny. The authority of science got deployed as laundered self-exculpation.

18 The authors, in a new line that appears in the paper's 2017 IJoC version, acknowledge the irony: "Even though the 2016 election may have replaced one form of populism with another-both forms holding experts of all stripes including economists in disdain-we believe that there is a constructive way to reinsert economic analysis into FCC decision making" (Faulhaber et al., 2017, p. 1229). 
The lesson for the field is that we should be paying close attention to funding and sponsorship-to what might be called the political economy of communication research. It is not just the media and telecommunications industries, but Silicon Valley too. Many of our brightest PhDs are heading to Menlo Park and Mountain View to staff company research shops. Nuance matters here; there is a big difference between the apparent autonomy of Microsoft Research and, say, Facebook, whose internal research arm has a record of publishing self-exonerating papers (Pooley, 2016). The point is that we need to stay alert, to call out declared and undeclared influence-never more so than when policy is at stake. The decisions before the FCC, in this moment of technological flux, may reverberate for decades to come.

\section{References}

Adams, W. (1954). The "rule of reason": Workable competition or workable monopoly? Yale Law Journal, $63(3), 348-370$.

AT\&T. (2012, November 7). AT\&T to invest $\$ 14$ billion to significantly expand wireless and wireline broadband networks, support future IP data growth and new services. Retrieved from https://www.att.com/gen/press-room?pid=23506

American Cable Association. (2014). Reply comments: FCC GN Docket No. 14-28, protecting and promoting the open internet. Washington, DC. Retrieved from

https://ecfsapi.fcc.gov/file/7522712388.pdf

Atkinson, R. (2013). Letter to Chairman Wheeler: Economic evidence on competition in communications markets and implications for key policy issues. Competition Policy International. Retrieved from https://www.competitionpolicyinternational.com/letter-to-chairman-wheeler-economicevidence-on-competition-in-communications-markets-and-implications-for-key-policy-issues/

Baker, J. (2013). Antitrust enforcement and sectoral regulation: The competition policy benefits of concurrent enforcement in the communications sector. Competition Policy International, 9(4). Retrieved from https://papers.ssrn.com/sol3/papers. cfm?abstractid=2313366

Baker, J., Bykowsky, M., DeGraba, P., LaFontaine, P. Ralph, E., \& Sharkey, W. (2011). The year in economics at the FCC, 2010-11: Protecting competition online. Review of Industrial Organization, 39, 297-309. Retrieved from http://papers.ssrn.com/abstract $=1920553$

Balto, D. (2015). United States Telecom Association v. Federal Communications Commission: A Petition for Review of an Order of the Federal Communications Commission. Washington, DC. Retrieved from https://apps.fcc.gov/edocs_public/attachmatch/DOC-334767A1.pdf

Bernstein, M. (2014). A perilous progress: Economists and public purpose in twentieth-century America. Princeton, NJ: Princeton University Press. 
Breger, M., \& Edles, G. J. (2015). Independent agencies in the United States: Law, structure, and politics. New York, NY: Oxford University Press.

Brennan, T. (2016). Is the Open Internet Order an "economics-free zone"? Free State Foundation: Perspectives from FSF Scholars, 11(22). Retrieved from http://www.freestatefoundation.org/images/Is_the_Open_Internet_Order_an_Economics_Free_ Zone_062816.pdf

Bring, D., Leighton, W., LoPiccalo, K., Matraves, C. Schwarz, J., \& Waterman, D. (2015). The year in economics at the FCC, 2014-2015. Review of Industrial Organization, 47, 437-462.

Brodkin, J. (2015, April 15). AT\&T, but not Verizon and Comcast, sue FCC over net neutrality. Ars Technica. Retrieved from https://arstechnica.com/tech-policy/2015/04/att-but-not-verizon-andcomcast-sue-fcc-over-net-neutrality/

CALinnovates. (2010a, October 3). How you phone is how you think: iPhone users more apt to believe in GOP takeover of Congress, be influenced by Tea Party, new poll find. Retrieved from http://www.calinnovates.org/how-you-phone-is-how-you-think-iphone-users-more-apt-tobelieve-in-gop-takeover-of-congress-be-influenced-by-tea-party-new-poll-find/

CALinnovates. (2010b, December 1). CALinnovates applauds FCC approach towards middle ground on net neutrality. Retrieved from http://www.calinnovates.org/calinnovates-org-applauds-fccapproach-towards-middle-ground-on-net-neutrality-2/

CALinnovates. (2010c, November 1). Form 990-EZ, return of organization exempt from income tax, 2009. Retrieved from http://pdfs.citizenaudit.org/2010_12_EO/26-4651773_990EO_200912.pdf

CALinnovates. (2011a, November 18). Desperately seeking spectrum. Retrieved from http://www.calinnovates.org/desperately-seeking-spectrum-event/

CALinnovates. (2011b, February 10). Member update. Retrieved from http://myemail.constantcontact.com/Member-Update---February-10-2011.html?soid=1102927891986\&aid=7oA3RUQRxLk

CALinnovates. (2011c, October 11). Towards universal broadband: Flexible broadband pricing and the digital divide. Retrieved from http://www.calinnovates.org/towards-universal-broadbandflexible-broadband-pricing-and-the-digital-divide/

CALinnovates. (2012a, November 15). Form 990, return of organization exempt from income tax, 2011. Retrieved from http://pdfs.citizenaudit.org/2012_12_EO/26-4651773_9900_201112.pdf 
CALinnovates. (2012b, November 13). \$14 billion additional investment in broadband networks means big things for consumers and innovators. Retrieved from http://www.calinnovates.org/14-billionadditional-investment-in-broadband-networks-means-big-things-for-consumers-and-innovators/

CALinnovates. (2015, November 14). Form 990, return of organization exempt from income tax, 2014. Retrieved from http://pdfs.citizenaudit.org/2016_01_EO/26-4651773_9900_201412.pdf

CALinnovates. (2016a, May 26). Comments of CALinnovates. Comments submitted to the Federal Communications Commission, WC Docket No. 16-106. Retrieved from https://ecfsapi.fcc.gov/file/60002067396.pdf

CALinnovates. (2016b, July 11). Lack of economic analysis at FCC harming innovation, economists find in CALinnovates report. PR Newswire. Retrieved from http://www.prnewswire.com/newsreleases/lack-of-economic-analysis-at-fcc-harming-innovation-economists-find-in-calinnovatesreport-300296165.html

CALinnovates. (n.d.) Staff: Executive director. Retrieved from http://www.calinnovates.org/about-us-22/executive-director/

Cannon, R. (2003). The legacy of the Federal Communications Commission's Computer Inquiries. Federal Communications Law Journal, 55(2): 167-205. Retrieved from http://www.repository.law.indiana.edu/cgi/viewcontent.cgi?article=1324\&context=fclj

Carare, O., Kiselev, E., Leighton, W., Levy, J., LoPiccalo, K., Sanyal, P., \& Waldon, T. (2016). The year in economics at the FCC, 2015-2016: Competition, merger review and spectrum management. Review of Industrial Organization, 48, 557-584.

Cecot, C. (2017, April 14). Make economics at the FCC great again. Washington, DC: Technology Policy Institute. Retrieved from https://techpolicyinstitute.org/2017/04/14/make-economics-at-thefcc-great-again/

Copeland, C. (2013). Economic analysis and independent regulatory agencies. Washington, DC: Administrative Conference of the United States. Retrieved from https://www.acus.gov/sites/default/files/documents/Copeland\%20Final\%20BCA\%20Report\%20 4-30-13.pdf

Craig, C. (2014, September 19). AT\&T's net neutrality proposal is a slick sidestep. InfoWorld. Retrieved from http://www.infoworld.com/article/2685642/net-neutrality/att-proposal.html

Daily Kos. (n.d.). CALinnovates's profile. Retrieved from http://www.dailykos.com/user/CALinnovates

Danielian, N. R. (1939). AT\&T: The story of industrial conquest. New York, NY: Vanguard. 
Delp, A., \& Mayo, J. (2016, July 22). The evolution of "competition": Lessons for 21st century telecommunications policy. Paper presented at the Future of the Internet Ecosystem in a PostOpen Internet Order World conference at the Technology Policy Institute and University of Pennsylvania, Washington, DC. Retrieved from http://cbpp.georgetown.edu/sites/ cbpp.georgetown.edu/files/Delp-Mayo-Effective-Competition.pdf

Dippon, C., \& Falk, J. (2014, September 9). Economic repercussions of applying Title II to Internet services (White paper submitted to FCC GN Docket No. 14-28, on behalf of CALinnovates). Washington, DC: NERA Economic Consulting. Retrieved from https://ecfsapi.fcc.gov/file/ 7522639528.pdf

Faturechi, R. (2014, October 10). Mysterious campaign appears to be the latest salvo in battle over net neutrality. ProPublica. Retrieved from https://www.propublica.org/article/mysterious-campaignappears-to-be-latest-salvo-in-net-neutrality-battle

Faulhaber, G. R., Hahn, R.W., \& Singer, H. J. (2012). Assessing competition in U.S. wireless markets: Review of the FCC's Competition Reports. Federal Communications Law Journal, 64(2), 319370. Retrieved from http://www.repository.law.indiana.edu/cgi/viewcontent.cgi ?article $=1616 \&$ context $=\mathrm{fclj}$

Faulhaber, G., \& Singer, H. J. (2016a). The curious absence of economic analysis at the Federal Communications Commission: An agency in search of a mission (White paper submitted to FCC Docket No. 16-106, on behalf of CALinnovates). Retrieved from https://ecfsapi.fcc.gov/file/10711657902329/FaulhaberSinger_FINAL\%20TO\%20FILE.pdf

Faulhaber, G., \& Singer, H. J. (2016b). The curious absence of economic analysis at the Federal Communications Commission (White paper submitted to FCC Docket No. 16-143, on behalf of CALinnovates). Retrieved from https://ecfsapi.fcc.gov/file/10822036857035/ FaulhaberSinger_FINAL\%20TO\%20FILE\%20BDS.pdf

Faulhaber, G., Singer, H., \& Urschel, A. (2017). The curious absence of economic analysis at the Federal Communications Commission: An agency in search of a mission. International Journal of Communication, 11, 1214-1233. Retrieved from http://ijoc.org/index.php/ijoc/article/view/ $6102 / 1967$

FCC. (2013a). Open Internet Advisory Committee 2013 annual report. Washington, DC: Author. Retrieved from https://transition.fcc.gov/cgb/oiac/oiac-2013-annual-report.pdf

FCC. (2013b). Policy issues in data caps and usage-based pricing economic impacts of Open Internet Frameworks Working Group. Washington, DC: Author. Retrieved from https://transition.fcc.gov/cgb/oiac/Economic-Impacts.pdf 
FCC. (2014a, May 29-30). The future of broadband workshop. Retrieved from http://comm.psu.edu/ research/centers/iip/conferences-and-worskhops/call-the-future-of-broadband-regulation

FCC. (2014b). Public notice: FCC announces a series of Open Internet roundtable discussions. Washington, DC: FCC. Retrieved from https://apps.fcc.gov/edocs_public/attachmatch/DA-141152A1.pdf

FCC. (2014c). Public notice: Policy approaches to ensure an Open Internet. Retrieved from https://ecfsapi.fcc.gov/file/7522895671.pdf

FCC. (2014d, October 2). Open Internet roundtable: Economics of broadband. Washington, DC: Author. Retrieved from https://www.fcc.gov/news-events/events/2014/10/open-internet-roundtableeconomics

FCC. (2014e). Letter from 19 economists re: protecting and promoting the Open Internet, GN Docket No. 14-28. Retrieved from https://ecfsapi.fcc.gov/file/60001008571.pdf

FCC. (2015a, January 30). Proposed Comcast-Time Warner Cable-Charter transaction economic analysis workshop. Washington, DC: FCC. Retrieved from https://apps.fcc.gov/edocs_public/ attachmatch/DOC-331873A1.pdf

FCC. (2015b, January 30). Proposed Comcast-Time Warner Cable-Charter transaction economic analysis workshop (January 30)-Proceedings. Washington, DC: FCC. Retrieved from https://ecfsapi.fcc.gov/file/60001031131.pdf

FCC. (2015c). Protecting and promoting the Open Internet. Washington, DC: FCC. Retrieved from https://apps.fcc.gov/edocs_public/attachmatch/FCC-15-24A1.pdf

FCC. (2015d). Recent transactions: Comcast-Time Warner Cable, MB Docket 14-57. Washington, DC: FCC. Retrieved from https://www.fcc.gov/transaction/comcast-twc

FCC. (2016a). Charter Communications, Inc., Time Warner Cable Inc., and Advance/Newhouse Partnership MB (Docket No. 15-149). Memorandum Opinion and Order. Retrieved from https://apps.fcc.gov/edocs_public/attachmatch/FCC-16-59A1.pdf

FCC. (2016b). International broadband data report, 5th Rpt. Washington, DC: FCC. Retrieved from https://apps.fcc.gov/edocs_public/attachmatch/DA-16-97A1.pdf

FCC. (2016c). Mobile wireless competition report, 19th Rpt. Washington, DC: FCC. Retrieved from https://apps.fcc.gov/edocs_public/attachmatch/DA-16-1061A1.pdf 
FCC. (2016d). Notice of OMB approval of the 2015 enhancements to the Open Internet transparency requirements. Washington, DC: Author. Retrieved from https://apps.fcc.gov/edocs_public/attachmatch/DA-16-1400A1Rcd.pdf

FCC. (2016e). Open Internet advisory committee. Washington, DC: Author. Retrieved from https://www.fcc.gov/about-fcc/advisory-committees/general/open-internet-advisory-committee

FCC. (2017a). Restoring Internet freedom: Notice of proposed rule making (Docket No. 17-108). Washington, DC: FCC. Retrieved from https://apps.fcc.gov/edocs_public/attachmatch/DOC344614A1.pdf

FCC. (2017b). Wireless telecommunications bureau report: Policy review of mobile broadband operators' sponsored data offerings for zero-rated content and services. Retrieved from https://apps.fcc.gov/edocs_public/attachmatch/DOC-342987A1.pdf

FCC. (n.d. [ECFS]). Electronic comment filing system. Washington, DC: FCC. Retrieved from https://www.fcc.gov/ecfs/

FCC. (n.d. [M\&As]). Mergers and acquisitions. Washington, DC: FCC. Retrieved from https://www.fcc.gov/proceedings-actions/mergers-and-acquisitions

FCC. (n.d. [Reports \& Research]). Economic seminars-Office of Strategic Planning and Policy Analysis. Washington, DC: Author. Retrieved from https://www.fcc.gov/reports-research

FCC. (n.d. [Seminars]). Economic seminars-Office of Strategic Planning and Policy Analysis. Washington, DC: Author. Retrieved from https://www.fcc.gov/general/economic-seminars-office-strategicplanning-policy-analysis

FCC. (n.d. [WP]). Working papers. Washington, DC: Author. Retrieved from https://www.fcc.gov/reportsresearch/working-papers

Franklin, J. (2016). A history of professional economists and policymaking in the United States: Irrelevant genius. London, UK: Routledge.

Galvin, T. (n.d.). Tom Galvin. LinkedIn. Retrieved from https://www.linkedin.com/in/togalvin/

Giuseppe, M. (2016, July 11). Former FCC chief economists say Wheeler has left economics behind. InsideSources. Retrieved from http://www.insidesources.com/former-fcc-chief-economists-saywheeler-has-left-economics-behind/

Goldmacher, S., \& York, A. (2012, April 22). AT\&T wields enormous power in Sacramento. Los Angeles Times. Retrieved from http://articles.latimes.com/2012/apr/22/local/la-me-att-20120422 
Holman, J., \& McGregor, M. A. (2001). "Thank you for taking the time to read this": Public participation via new communication technologies at the FCC. Journalism and Communication Monographs, 2(4), 158-202.

Hovenkamp, H. (2008). The antitrust enterprise. Cambridge, MA: Harvard University Press.

Hurwitz, G. (2016, July 19). Economic analysis in an age of deference. Tech Policy Daily. Retrieved from http://www.techpolicydaily.com/communications/economic-analysis-age-deference/

Jansen, S. C. (2017). Stealth communications: The spectacular rise of public relations. Cambridge, UK: Polity.

John Zogby Strategies. (n.d.). Portfolio archives: Corporate. Retrieved from http://johnzogbystrategies.com/project-category/corporate/

Kahn, A. (1954). A legal and economic appraisal of the "new" Sherman and Clayton Acts. Yale Law Journal, 63(3), 293-347.

Kahn, A. (1988). The economics of regulation. Cambridge, MA: MIT Press.

Kasselman, L. (n.d.). Lane Kasselman. LinkedIn. Retrieved from https://www.linkedin.com/in/kasselman/

Klass, B., Winseck, D., Nanni, M., \& Mckelvey, F. (2016). There ain't no such thing as a free lunch: Historical and international perspectives on why common carriage should be a cornerstone of communications policy in the Internet age. Submission to the CRTC's review of differential pricing proceeding (CRTC 2016-192). Retrieved from https://services.crtc.gc.ca/pub/ ListeInterventionList/Documents.aspx?ID=234586\&en=2016-192\&dt=i\&lang =e\&S $=C \& P A=T \& P T=N C \& P S T=A$

Knutson, R. (2015, April 14). AT\&T sues to overturn FCC's net neutrality rules. The Wall Street Journal. Retrieved from https://www.wsj.com/articles/at-t-sues-to-overturn-fccs-net-neutrality-rules1429052166

Lehane, E. M. (2010, December 9). Notice of ex parte presentation of CALinnovates, FCC GN Docket No. 09-191 and GN Docket No. 10-127. Retrieved from https://ecfsapi.fcc.gov/file/7020922799.pdf

Lipton, E., Confessore, N., \& Williams, B. (2016, August 8). Think tank scholar or corporate consultant: It depends on the day. The New York Times. Retrieved from https://www.nytimes.com/2016/08/ 09/us/politics/think-tank-scholars-corporate-consultants.html

Litan, R., \& Singer, H. (2014, December). Outdated regulations will make consumers pay more for broadband. Notice of ex parte filing in Open Internet Order (14-28). Washington, DC: Progressive Policy Institute. Retrieved from https://ecfsapi.fcc.gov/file/60001009825.pdf 
Lopes, M. (2014, November 12). AT\&T to pause fiber spending on net neutrality uncertainty. Reuters. Retrieved from http://www.reuters.com/article/us-at-t-regulations-internetidUSKCNOIW1JC20141113

McGregor, M. A. (2006). When the "public interest" is not what interests the public. Communication Law and Policy, 11(2), 207-224.

Montgomery, M. (2012, August 7). New FCC commissioners a breath of fresh air. Huffington Post. Retrieved from http://www.huffingtonpost.com/mike-montgomery/new-fcccommissioners_b_1738959.html

Montgomery, M. (2014a, September 11). Notice of ex parte presentation of CALinnovates, FCC GN Docket No. 14-28. Retrieved from https://ecfsapi.fcc.gov/file/7522006039.pdf

Montgomery, M. (2014b, September 11). Reply comments of CALinnovates. Comments submitted to the Federal Communications Commission, FCC GN Docket No. 14-28. Retrieved from http://www.calinnovates.org/wp-content/uploads/2014/09/2014.09.11-FINAL-CALinnovatesComments.pdf

Montgomery, M. (2014c, October 29). Notice of ex parte presentation of CALinnovates, FCC GN Docket No. 14-28. Retrieved from https://prodnet.www.neca.org/publicationsdocs/wwpdf/102914cal.pdf

Montgomery, M. (2015a, February 26). CALinnovates statement on Federal Communications Commission vote on Open Internet. $P R$ Newswire. Retrieved from http://www.prnewswire.com/newsreleases/calinnovates-statement-on-federal-communications-commission-vote-on-openinternet-300042154.html

Montgomery, M. (2015b, June 3). The 2016 net neutrality time bomb. Medium. Retrieved from https://medium.com/@calinnovates/the-2016-net-neutrality-time-bomb-6bac50e0b7ab

Montgomery, M. (2016, July 11). [Letter to Marlene H. Dortsch]. Submitted to FCC WC Docket No. 16106. Retrieved from https://ecfsapi.fcc.gov/file/10711657902329/ FaulhaberSingerFINAL\%20TO\%20FILE.pdf

Montgomery, M. (2017a, February 7). CALinnovates calls on Congress to enact bipartisan net neutrality legislation. CALinnovates. Retrieved from http://www.calinnovates.org/calinnovates-callscongress-bipartisan-net-neutrality-legislation/

Montgomery, M. (2017b, January 23). CALinnovates lauds President Trump's appointment of Ajit Pai as new FCC chairman. CALinnovates. Retrieved from http://www.calinnovates.org/calinnovateslauds-president-trumps-appointment-ajit-pai-new-fcc-chairman/ 
Montgomery, M. (2017c, February 10). In these chaotic times, Democrats need to rethink priorities. Morning Consult. Retrieved from https://morningconsult.com/opinions/chaotic-times-democratsneed-rethink-priorities/

Napoli, P. (2008). Paradoxes of media policy analysis: Implications for public interest media regulation. Administrative Law Review, 60(4), 801-812.

Neuchterlein, J. E., Zachary, H. M., Deacon, D. T., Heimann, C. M., Phillips, G. L., \& Garber, P. (2012, November 7). Petition to launch a proceeding concerning the TDM-to-IP transition. Petition submitted to the Federal Communications Commission. Retrieved from http://newnetworks.com/ATTFCC2012.pdf

Noam, E. (2009). Media ownership and concentration in America. New York, NY: Oxford University Press.

Noam, E. (Ed.). (2016). Who owns the world's media? New York, NY: Oxford University Press.

Office of Communication of the United Church of Christ v. Federal Communications Commission, 359 D.2d 994 (DC Cir., 1966).

Organisation for Economic Co-operation and Development. (2017). OECD broadband portal. Geneva, Switzerland: Author. Retrieved from https://www.oecd.org/sti/broadband/ oecdbroadbandportal.htm

Pai, A. (2017a, May 5). The first 100 days: Bringing the benefits of the digital age to all Americans, Washington, DC. Speech to the American Enterprise Institute. Retrieved from https://www.fcc.gov/document/chairman-pai-speech-first-100-days

Pai, A. (2017b, April 5). Remarks of FCC Chairman Ajit Pai at the Hudson Institute: The importance of economic analysis at the FCC. Retrieved from https://transition.fcc.gov/DailyReleases/ DailyBusiness/2017/db0405/DOC-344248A1.pdf

Pai, A. (2017c, April 26). Remarks of FCC Chairman Pai at the Newseum: The future of Internet freedom. Retrieved from https://transition.fcc.gov/Daily_Releases/Daily_Business/2017/db0426/DOC344590A1.pdf

Pooley, J. (2016, November 11). Why we can't know whether Facebook is to blame for Trump's election. Slate. Retrieved from http://www.slate.com/blogs/future_tense/2016/11/ 11/we_can_t_know_whether_facebook_is_to_blame_for_trump_s_win.html

Progressive Policy Institute. (2014). Notice of ex parte filing in Open Internet Order (14-28). Washington, DC: Author. Retrieved from https://ecfsapi.fcc.gov/file/60001026180.pdf 
Romm, T. (2016, October 7). Trump transition team picks regulation foe as telecom point man. Politico. Retrieved from http://www.politico.com/story/2016/10/trump-transition-team-jeffrey-eisenach229276

Sallet, J. (2015, September). The Federal Communications Commission and lessons of recent mergers and acquisitions reviews. Paper presented at Telecommunications Policy Research Conference (TPRC 43), George Mason University, Arlington, VA. Retrieved from https://apps.fcc.gov/edocs_public/attachmatch/DOC-335494A1.pdf

Sklar, M. (1988). The corporate reconstruction of American capitalism, 1890-1916. New York, NY: Cambridge University Press.

Streeter, T. (1996). Selling the air. Chicago, IL: University of Chicago Press.

Stucke, M., \& Grunes, A. (2016). Big data and competition policy. New York, NY: Oxford University Press.

Sunstein, C. (2013). Commentary: The Office of Information and Regulatory Affairs: Myths and realities. Harvard Law Review, 126, 1838-1878. Retrieved from http://thecre.com/pdf/ 20130523_vol126_sunstein.pdf

Taylor, G. (2013). Oil in the ether: A critical history of spectrum auctions in Canada. Canadian Journal of Communication, 38(1), 121-137.

Telecom Regulatory Authority of India. (2016, February 8). Prohibition of discriminatory tariffs for data services regulations (decision). New Delhi, India: Author. Retrieved from http://trai.gov.in/ WriteReaddata/ConsultationPaper/Document/CP-Differential-Pricing-09122015.pdf

Thune, J. (2016, July 12). How will the FCC's proposed privacy regulations affect consumers and competition? Hearings before the Subcommittee on Commerce Science, and Transportation, 114th Cong. (Opening statement of Sen. John Thune). Retrieved from https://www.commerce.senate.gov/public/index.cfm/hearings?Id=1A0FC3ED-B203-4B2F-8892DF01C1C7001E\&Statementid=EF4A3B9C-2405-4667-848D-2882A11E2B53

United States Court of Appeals, DC Circuit. (2014). Verizon v. FCC. Retrieved from https://www.cadc. uscourts.gov/internet/opinions.nsf/3AF8B4D938CDEEA685257C6000532062/ \$file/11-1355-1474943.pdf

United States Court of Appeals, DC Circuit. (2016). United States Telecom, et al. v. FCC. Retrieved from https://www.cadc.uscourts.gov/internet/opinions.nsf/3F95E49183E6F8AF85257FD200505A3A/\$ file/15-1063-1619173.pdf 
U.S. Census Bureau. (2017a). 2017 capital spending report tables, Table 4a: Capital expenditures for structures and equipment for companies with employees by industry sector: 2006 to 2015. Washington, DC: Author. Retrieved from https://www.census.gov/data/tables/timeseries/econ/aces/2017-csr.html

U.S. Department of Justice. (2011, September 16). United States and Plaintiff States v. AT\&T Inc., TMobile USA, Inc. and Deutsche Telekom AG (Amended complaint). Washington, DC: Author. Retrieved from http://www.justice.gov/atr/cases/f275100/275128.pdf

U.S. Department of Justice. (2017). Division economists help shape enforcement projects-Division update, spring 2016. Washington, DC: Author. Retrieved from https://www.justice.gov/ atr/division-operations/division-update-2016/division-economists-help-shape-enforcementefforts 